Duxbury, Nancy. (Forthcoming in 2020). Cultural and creative work in rural and remote areas: An emerging international conversation. International Journal of Cultural Policy. Accepted for publication October 2020.

\title{
Cultural and creative work in rural and remote areas: An emerging international conversation
}

\author{
Nancy Duxbury \\ Centre for Social Studies, University of Coimbra \\ Colégio S. Jerónimo, Apartado 3087, 3000-995 Coimbra, Portugal \\ duxbury@ces.uc.pt \\ ORCiD ID: 0000-0002-5611-466X
}

\begin{abstract}
This article reports on the themes and trajectories of a multidisciplinary and international literature. It reveals how cultural and creative work in rural and remote areas has largely been examined and articulated through three storylines: (1) cultural vitality, that is, culture as a resource for community development; (2) the 'rural creative class', recently linked to rural innovation; and (3) rural creative economies and creative entrepreneurship in rural and remote areas. Over the past decade, these strands of discourse have become more intertwined in policy and planning documents, suggesting an opportunity for converging these discussions into a more comprehensive approach to fostering cultural and creative work in rural and remote areas. However, cultural policy directed to rural areas remains underdeveloped compared to its urban counterpart.
\end{abstract}

Keywords: culture-based development, cultural work in rural and remote areas, rural creative economy, rural creative class

\section{Introduction}

In October 2019, Culture Action Europe organized the conference "Culture Crops: Cultural Practices in Non-urban Territories" to foster debate and develop a more comprehensive approach to culture and cultural and artistic practices in peripheral territories (Cotte, 2019). In February and April 2020, meetings on the topic of "The Role of Culture in Non-urban Areas of the European Union" were organized as part of the "Voices of Culture" structured dialogue initiative between the European Commission and the cultural sector. These events occurred in the context of a perceived urban-centric bias in European cultural policy, inequity of access to opportunities for non-urban based creators, and misunderstandings about the realities of nonurban creative work situations. In the end, cultural participants in the EU dialogue put forward over 50 recommendations for action (Murphy and Cameron, 2020).

In the United States, in January 2019, the National Governors Association (in partnership with the National Endowment for the Arts and the National Assembly of State Art Agencies) published an "action guide" entitled Rural Prosperity Through the Arts and Creative Sector: A Rural Action Guide for Governors and States (Rood, 2019). While following on from a highprofile report focusing on rural artistic and creative work and economic innovation (NEA, 2017), this document is broader in its scope and sets out a Rural Systems Change Framework for Governors/States that incorporates and aims to foster both "economic and quality-of-life outcomes associated with the rural creative sector" (p. 3).

In Australia, a number of research projects on cultural work and creative arts in smaller communities are underway. For example, the "Creative Ecologies" project, launched in 2018, is a collaborative investigation "to understand what it takes to build thriving creative 
communities and develop tools to foster their growth" (Future Tense, 2018, 5). The project is a national initiative of Future Tense in partnership with Artlands Victoria, RMIT University, Ludowyk Evaluation, and Clear. It is attending to both urban and non-urban/regional contexts. Another in-process multi-partner project, "The Role of the Creative Arts in Regional Australia: A Social Impact Model," is designed to highlight the social impact of the creative arts for regional and remote communities and to deliver a framework for evaluating the arts within a broader understanding of community well-being and success (led by Queensland University of Technology researchers Sandra Gattenhof, Donna Hancox, Helen Klaebe; https://research.qut.edu.au/raasi/).

Is cultural work in non-urban areas an emerging agenda? What is the cultural policy research base to inform and advise this situation? The neglect of rural cultural matters in academic spheres has been long discussed (e.g., Rooney and Smith, 2008; van Heur, 2010). How has research progressed since this time? What are the main trajectories it has followed? To investigate this situation, an international multidisciplinary literature review on cultural and creative work in rural and remote areas was conducted. It examined both academic and grey literature, including documents and other initiatives produced by governments at different levels and as well as by cultural organizations and agencies. The review focuses primarily on English-language literature, with a few non-English-language sources indicating similar discussions. While lines of research and discussion are identifiable, in the messiness of real-life narrative trajectories, they are not completely separate, and some merging or overlapping of evolving discussions is evident. Categorization of the literature focused on the primary nature of the discourse in which works were received and with which they best aligned. Efforts to track lines of discourse chronologically also informed these choices. While it is impossible to have included all relevant publications, the review served to identify and sketch out some of the main conceptual pathways and research trajectories of the research and writings relating to cultural and creative work in rural areas.

The complexities of terminologies relating to cultural and creative work are well documented in Donald and Hall (2014), Long and Morpeth (2016), and Collins and Cunningham (2017), among others, and are not elaborated here. However, as with many comprehensive reviews of a wide variety of types of documents about cultural development, the definition involved varies from culture-based enterprises, to artistic creation, to the broader cultural expressions and ways of life of a community. In the review, the scope of "culture" that was being discussed was considered, but focused more on the contextualization of how culture was being mobilized. Similarly, terms of rural, remote, non-urban, extra-metropolitan, and low-density territories, among others, are used within this literature, and the main criteria for inclusion was an extraurban focus.

Thus, this article presents a general conceptual cartography of the key themes and trajectories of discourses in the literature, beginning around about 2005, and points to some recent and current initiatives that suggest an opportunity to interweave the discourses. In closing, it outlines key topics in policy recommendations proposed in recent research literature and suggests follow-on research that would further inform these policy-research discourses and advance rural cultural policy.

\section{From cultural development to cultural and creative work}

Looking back, a landmark scan and survey of policy-related research and policy practices relating to cultural development in rural and remote areas was conducted in 2006 by Ruth Smiles of Regional Arts Australia for the International Federation of Arts Councils and Culture 
Agencies (Smiles, 2006). The report compiled and reviewed publications (a mix of academic and arts-council research projects, and mainly English-language materials), conferences and events, and other resources, including projects, organizations, and networks. Smiles reported that "while much of the focus for the research and discussion about the arts in rural and remote areas is about sustainable economic development, it is the value of the arts for cultural and social well being that predominates in forums and conferences" (p. 3). This insight reflects the bi-focal approach to the topic that has largely characterized and contributed to the fragmented nature of writings about cultural development in rural areas.

Over the last 15 years, a crescendo of social, economic, cultural, and political messages and experiments have spread wide and far, with multiple arguments and conversational threads, special initiatives, and local experimentation. Research literature on culture-based and creative work in rural and remote areas has stressed the importance of foregrounding the interconnected world of creative production as networks and flows of people, information, and creative production, and to maintain an approach that is more complicated than the image of a simple city-country divide (Burns and Kirkpatrick, 2008; Gibson, 2014). At a strategic local development and community planning level, a "cultural" turn in rural planning has encouraged greater attention to the role of culture in the construction of rural identities and futures (e.g., Nelson et al., 2012; Selfa et al., 2015; Campbell and Maclaren, forthcoming).

This sense of possibility has been coupled with warnings of the potential harm of introducing inappropriate frameworks to rural-based cultural initiatives; ongoing debates about the appropriateness of 'urban' definitions and approaches to examine, describe, and understand rural realities of culture-based and creative work; and questioning of the idea of transferring 'urban-centric' creative economy policies and practices to rural locations (e.g., McCool and Moisey, 2001; Gibson and Klocker, 2005; Cruickshank, 2016). Policy to support cultural activity and enterprises in rural contexts continues to be fractured and appears to be underdeveloped. This article results from a desire to bring together many threads of discourse and to synthesize and better understand the research and policy-related work that has been conducted for rural contexts in order to progress forward on a more consolidated foundation.

Overall, the research found that culture-based and creative work in rural and remote areas has largely been examined and articulated through three storylines: (1) cultural vitality, that is, culture as a resource for community development; (2) the 'rural creative class', recently linked to rural innovation; and (3) rural creative economies and creative entrepreneurship in rural and remote areas. An overview of key themes in these trajectories is presented in Figure 1. All three storylines are still actively in force, individually and sometimes joined-up/mixed. As new research and policy-related initiatives emerge, it seems a timely point to better understand, reconcile, and perhaps converge these somewhat parallel discussions into a more comprehensive approach to fostering cultural and creative work in rural and remote areas. 


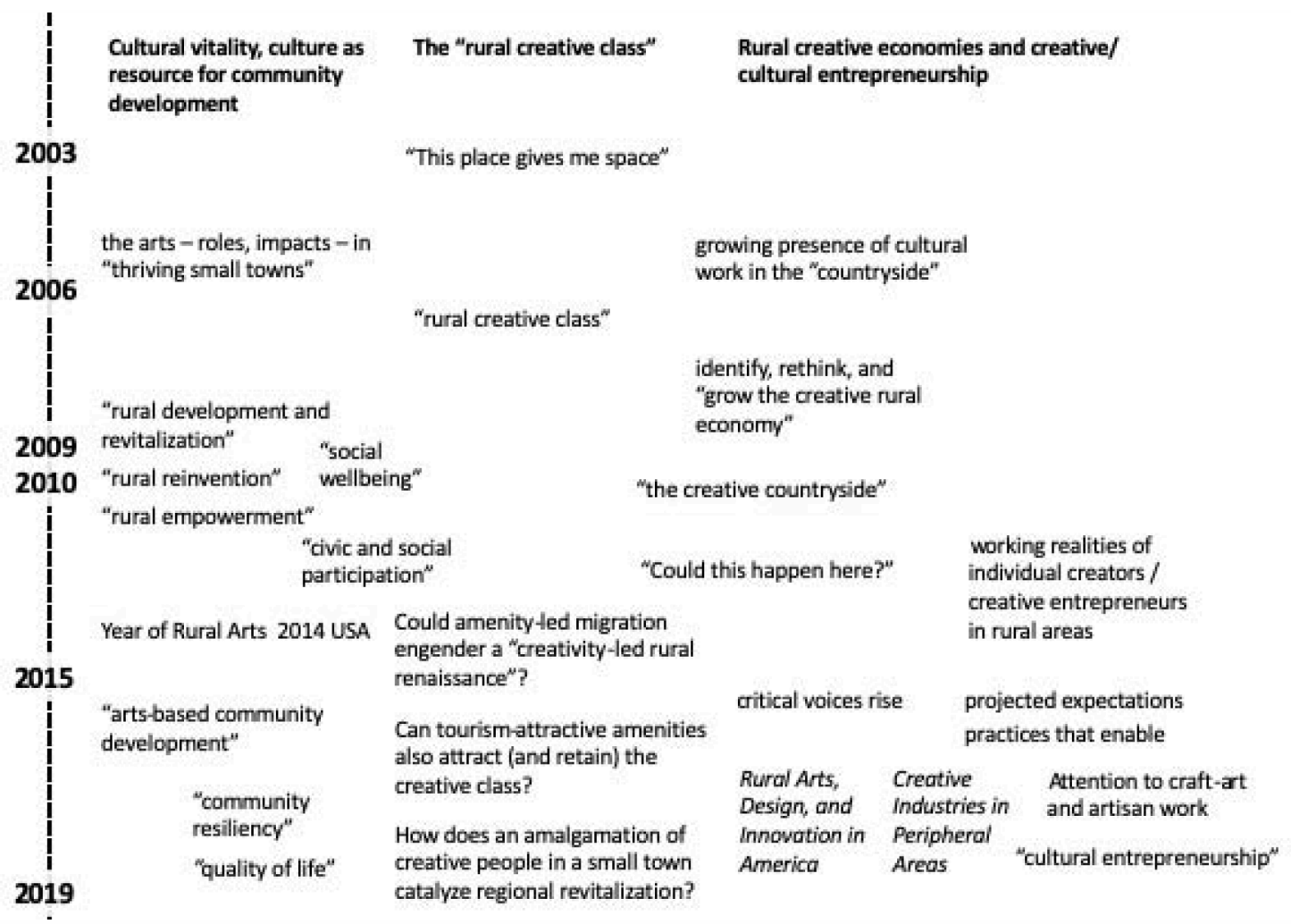

Figure 1. Trajectories of key themes in the literature

\section{Cultural vitality: Culture as resource for community development}

In the midst of economic challenges and transitions, and bolstered by residents' desire to regain a community-based self-determination (Overton, 2009), many smaller communities have been recognizing that a clear sense of self - the ways the community understands, celebrates, and expresses itself - is a major contributing factor to its ability to withstand economic, political, and cultural winds of change and transition (Duxbury, 2010; Campbell and Maclaren, forthcoming). In this context, arts, culture, and heritage have been viewed as more than amenities to improve the quality of life but as a foundation upon which the future of these $\mathrm{rural} / \mathrm{small}$ communities rests. Cuesta et al. (2005) argue that the arts and creative activities can profoundly affect the ability of a town not only to survive over time but to thrive.

Around 2005-06, investigations on the roles and impacts of the arts in "thriving small towns" emerged in the United States. On the basis of close examination of a series of small towns in the state of Michigan (U.S.), Shifferd (2005) and Rodning Bash (2006) identified key ingredients that outlined a progression of artistic development from emerging to sustaining to mature, a continuum "from nascent, isolated and episodic, to highly integrated and sustained, involving significant numbers of people" (Shifferd, 2005, 8). Reoccurring ingredients identified in this research that fostered the arts and creative development in small and rural communities included:

- An underlying appreciation and attitude of acceptance toward local culture, history, people and assets, and a community's 'sense of place';

- A valuing of the arts in everyday life, and an inclusive encouragement of broadbased participation; 
- Key leadership roles representing the broad community, and a community-based coalition willing to work towards a common goal;

- Social networks of volunteers and arts supporters who work on exhibitions, festivals, community cultural development projects; support artists in their community-regeneration efforts; and inclusively encourage vibrancy among all cultural groups in a community; and

- Cultural infrastructure development-Cultural facilities and centres are important 'gathering places', functioning as a cornerstone of community cohesion and community building. Support for this infrastructure, either as part of new developments or as maintenance of existing facilities, is essential to create a visible focus of efforts and to offer a physical point of contact for diverse community groups. (Duxbury, 2010)

These dimensions aptly illustrate this holistic approach, which focuses on arts practices embedded within a broader community for the social well-being of that community and its development, as well as to foster civic and social participation (Anwar, 2005) and, later on, "community resiliency" (Ortiz, 2017). At this time, Markusen and Schrock (2006) elaborated the various dimensions of an (economic) "artistic dividend" that accrues to rural regions with a thriving cultural community, followed by an article on an arts-based state rural development policy (Markusen, 2007). This work continues to resonate strongly in research on artistic activity in rural areas and has anchored numerous rural development strategies and planning efforts in North America (e.g., Donald and Hall, 2014).

This discussion was soon situated in the context of "rural development and revitalization" (Duxbury and Campbell, 2009), "rural reinvention" (Gibson and Stewart, 2009), and "rural empowerment" (Anwar McHenry, 2011), which strengthened into discussions of "arts-based community development" by 2016 (Skippington and Davis, 2016). Initial investigations into identifying supportive contexts in 2005 morphed into more direct "cultivating" of this development (Donald and Hall, 2014). In 2014, arts and culture in rural areas of the United States were given a significant spotlight through a national "Year of the Rural Arts," fueled by an NEA grant to a partnership between Art of the Rural, The Rural Policy Research Institute, and national networks for the project "Next Generation", with the topic taken up by Americans for the Arts and featuring the development of a wide array of online resources and events. ${ }^{1}$

Other research in this stream has incorporated contexts of holistic local sustainable development, culturally informed/resonant local development, and local resiliency. For example, in rural Western Australia, Anwar McHenry (2011) observed that the arts, in their capacity to explore community identity and strengthen a sense of place, were key to encouraging and enabling civic participation to identify and resolve local problems, and to facilitate understanding between groups, vitally contributing to efforts relating to common objectives and thus fortifying resilience. A critical look at the perceptions and challenges of the social benefits and "usefulness" of the arts in 12 rural remote communities in Australia (Skippington and Davis, 2016, 237) found:

\footnotetext{
${ }^{1}$ Online resources include: Art of the Rural website (http://artoftherural.org), Atlas of Rural Arts and Culture (http://placestories.com/community/RuralArtsAndCulture), and an Americans for the Arts blog on "Arts Resources for Rural America” (https://www.americansforthearts.org/blog-feed/arts-resources-for-rural-america), while events included "Rural Assembly: Building an Inclusive Nation," "Cross Currents: Art+Agriculture Powering Rural Economies," and Rural Arts Happy Hour virtual conversations.
} 
the remote/rural processes examined were usually aimed solely at social outcomes, increasing community networking and maintaining social cohesion. The research identified little or no appreciation in remote/rural communities of the potential to use the arts to generate and/or support economic outcomes. ... Arts-based activities in the remote/rural communities examined in this research generally sit apart from major community planning agendas involving plans to increase tourism, attract workers, attract new businesses, build community infrastructure and improve the liveability of communities.

These authors argue that this situation must be challenged in order to "develop comprehensive and integrated visions for the future, pursuing less insular and narrowly focused art forms and projects," and encourage artists to "think more broadly and comprehensively and be prepared to contribute their knowledge and creative skills across the full spectrum of community development." (p. 237)

A similar argument was brought forward during a Digital Gathering on the topic of "Cultural Development in Rural and Remote Areas" organized by Mass Culture/Mobilisation Culturelle in Canada, in March 2019. Invited speaker Annalee Adair remarked:

Culture can address to real issues only if it sees itself as contributing to community quality of life and not only advocating for the sector. A shift in perspective is needed: What is our contribution to our community as cultural organizations, as creators, as historians, as museums ...? What is our part in ensuring out community identity is authentic and vital? And how does that then help the community as a whole? The role of culture in a community, and in community building and community vitality [needs to be discussed more] ... culture is not a separate issue, it is integral to community identity, but it is sometimes seen as only for some people to participate in.

One trajectory forward in this discourse can be found in Jude Ortiz's doctoral dissertation research in northern Ontario (Canada) communities on the contributions of arts practice to community resilience (Ortiz, 2017). Ortiz found that local cultural goods provide a means of greater community self-understanding and that engagement in arts processes develops competencies that align with those needed to manage community change and continual adaptation:

processes inherent to engagement in the arts fosters divergent perspectives, creative problem solving and an ability to work with complexity, emergence and uncertainty at an individual and community level; all important skills to deal with change. The production of cultural goods leads to increased understanding of self and others in the context of place, enabling identity reformation and belonging, health and well-being and agency, as well as the development of a localized economy. Furthermore, the research highlights similarities between artistic and community developers' practice suggesting that capacities gained through engaging in the arts parallel those necessary for developers to work effectively within emergent, inclusive, and holistic approaches that underpin continuous community adaptation in addressing change. (1)

Such research recognizes artistic practices as intertwined with processes of planning for local community development, adaptation, and resilience. It is important to note, however, that the broader discourse on resiliency has been accompanied by substantial critiques of the idea of resilience as enabling or excusing patterns of de-funding and/or the lack of adequate policy to 
support rural communities, and instead placing responsibility back onto the communities themselves. Thus, situating culture within this broader resiliency discourse must balance advancing considerations of culture within empowering local agency with critical awareness of broader policy arrangements, constraints, and other situational contexts. Overall, calls to integrate cultural production and expression more soundly into the mainstream of community planning for holistic sustainable development and local resiliency continue to be advanced in policy-related documents such as Rood (2019), Cotte (2019), and Murphy and Cameron (2020).

\section{The "rural creative class"}

The second stream of discourse relates to the attraction and retention of a "rural creative class." In the early 2000s, as the pervasiveness of discussions about the "creative class" (Florida, 2002) and urban centrality proliferated internationally, the discourse created shock waves in smaller places struggling to see themselves in this reframing of "what it takes to be successful," economically (and otherwise) (Lewis and Donald, 2010, Bennett, 2010, Yuzwa, 2017). Political discussions and various writings spoke of talent attraction and (to a lesser extent) retention, and related possibilities in this new economic context. Consequently, in the context of economic transitions and the threat (or reality) of decline, for at least a decade, rural communities have aimed to attract the "creative class" as residents-with-businesses, within a broader economic emphasis on entrepreneurship and small businesses. This pattern continues internationally, framed by regional, national, and supranational rural development policy frameworks, although on the ground, tending to occur in more informal and incremental ways.

In terms of research, while a 2003 study from the U.K., "This place gives me space" (Drake, 2003), provided first-hand accounts from rural creators, this was quickly superseded by statistically defined quantitative approaches to identify the "rural creative class" (McGranahan and Wojan 2007a, 2007b; Wojan et al., 2007), with a particular focus on who moves from urban areas, how they differ from their urban counterparts, where they locate, and how a place could attract them. Largely based in the United States (but not entirely), research found that artists and creative entrepreneurs located in rural areas tend to be older and have established businesses and markets (Hracs, 2005; McGranahan and Wojan, 2007b; Wojan et al., 2007; Andersen, 2010; Bennett et al., 2015).

Research found that artists move to smaller communities and rural areas as they flee the high rents of urban centres and seek a rural/small community "quality of life" and lifestyle amenities (Burns and Kirkpatrick, 2008; Andersen, 2010; Verdich, 2010; Denis-Jacob, 2012; Herslund, 2012; Felton and Collis, 2012; Collis et al., 2013; Bennett et al., 2015; Daniel, 2014) —with a good Internet connection. This theme inspired work internationally, for example: in Australia, Argent et al. (2013) ask, "Could amenity-led migration engender a "creativity-led rural renaissance?"; and in Portugal, Cruz (2016) asks, "Can tourism-attractive amenities also attract (and retain) the creative class?". This work dovetailed with more general work on rural entrepreneurs, such as Haisch et al. (2017) who, in central European contexts, ask, "Why do entrepreneurial individuals locate in non-metropolitan areas?". These types of investigations marked a return of first-hand accounts and fueled interest in creative entrepreneurs in rural areas.

Of course, these urban-to-rural migrations (counter-urbanism) play out more broadly on a societal basis. McManus and Connell (2008) saw this phenomenon as a relatively wealthy middle-class group withdrawing from urban settings to pursue a different lifestyle in a rural location, fueled by rising urban housing costs and quality of life concerns, as well as life transitions such as starting families or retirement. More recently, the migration of a younger 
cohort in their 20s and 30s is also observed, in Japan and elsewhere, propelled by a set of values that prioritizes environmental connection and sustainability and personal well-being within smaller community settings (e.g., Noda, 2018). According to various news stories and public polls, the Covid-19 pandemic in 2020 has also sparked interest in moving from urban to lessurban areas in the U.S. (e.g., Hart, 2020) and U.K. (Rightmove, 2020), among other countries, although how this will play out is still yet to be seen.

An important context for rural and remote cultural activities and enterprises has been the availability and capabilities of broadband Internet, which is a key enabler of the move from urban to rural areas (Bowles, 2008; Burns and Kirkpatrick, 2008; Donald, 2008; Roberts and Townsend, 2015). The need for connection - to others, to markets, to sources of inspiration and trends, to broadcast oneself outward - is a reoccurring theme. This reflects the centrality of the Internet as a marketing tool (Duxbury and Campbell, 2009), the need for access to platforms central to growing cultural sharing practices, especially among youth; and the need for cultural producers to keep within broader production networks. As Donald and Hall $(2014,5)$ elaborate, "artistic and creative activity in rural places feeds into larger cultural industry value chains." Anderson et al. (2015) tentatively argue that broadband technology proffers "a new rural geography: the creative countryside which is culturally inspired and entrepreneurially driven and in which place increasingly supersedes space in terms of importance" (Collins and Cunningham, 2017, 37).

Where do they locate? In the United States, Wojan et al. (2007) identified about 100 rural "creative havens," which tend to be in relatively close proximity to and have good connections to major metro areas; are home to a major university or college; or have considerable natural amenities which draw people to them. Jumping forward, a 2017 study by the U.S. National Endowment for the Arts found that a rural county is $60 \%$ more likely to contain a performing arts organization if the county overlaps with a forest or national park (NEA, 2017). Similar attractors have been identified elsewhere.

In 2018, Wojan and Nichols examined the correlation between the presence of arts and design organizations and commitment to innovation in other businesses in "rural creative places" in the United States. They noted that their findings supported both an "arts-as-enabler-ofinnovative-thinking" explanation and an "arts-as-attractive-creative-class-amenity" explanation, concluding that "as a local development strategy, promoting the arts is likely to have a positive impact that extends beyond a direct economic impact to affecting the capacities of businesses reliant on design and innovation, either by attracting or enabling creative talent" (n.p.). ${ }^{2}$ Amplifying this trajectory, Richard Florida (2018) recounts the 2017 NEA research report and the Wojan et al. studies to highlight the importance of the presence of a "rural creative class" to rural innovation in the United States:

Wojan and company's analysis find a strong statistical association between the arts, innovation, and economic dynamism in rural areas. And this leads them to conclude that the arts are a direct force in rural innovation, not just an indirect factor that helps to attract and retain talent.

Artists and creatives in America have long sought out rural places to fuel their creativity .... But the arts in rural places are not just a byproduct of the scenery; they play a key role in spurring the innovation that ultimately leads to economic development and rising

\footnotetext{
${ }^{2}$ This research on rural innovation rests on companies of five or more employees, which ignores a broad range of activities and production undertaken by smaller collectives and individuals.
} 
living standards. The myth that urban areas are creative and rural areas are not is just that: a myth. (n.p.)

With this swing in focus, a stream of attention to the greater economic (and other) impacts of the businesses of the "rural creative class" is anticipated to continue.

\section{Rural creative economies and creative entrepreneurship in rural and remote areas}

Closely aligned with the investigations into the "rural creative class," one can observe two groups of research literature, albeit with different focal points: first, a collective or macro perspective on investigating "rural creative economies" is evident from at least 2005; and second, a closer attention to the realities of the creative entrepreneurs operating in rural and remote areas, only significantly evident around 2011-2012.

\section{Rural creative economies}

Between 2005 and 2010, an international burst of writings on rural creative economies is evident. In 2005, Brian Hracs noted growing presence of cultural work in the "countryside" in Canada, connecting this with economic development and social change (Hracs, 2005). In Australia, Gibson and Klocker (2005) observed a "cultural turn" in regional development discourse, incorporating a neoliberal perspective on creativity. By 2008, one can observe expanded efforts to identify, rethink, and "grow the creative-rural economy" (Donald, 2008, i), with authors writing on this theme from Canada, U.K., Ireland, Scotland, Germany, Turkey, Netherlands, Australia, Japan, and the United States. Many articles on this topic were published in the Creative Industries Journal, which launched in 2008. In 2010, Bell and Jayne's (2010) seminal work on "the creative countryside" investigated policy and practice in the UK "rural creative economy." The same year, Chris Gibson edited a special issue of Australian Geographer on "Creativity in 'Peripheral' Areas: Redefining the Creative Industries," which was subsequently republished in book form in 2014.

By 2011, policy-makers took note, with policy-oriented events organized in Canada, and the U.K. that year, focusing largely on urban-rural creative economy connections (see, e.g., MacDonald, 2011; Martin Prosperity Institute, 2011). In 2012, a second wave of articles emerged asking "Could this happen here?"; for example, "Dream or reality?" (Denis-Jacob, 2012, Canada) and "What is the potential in remote areas?" (Skoglund and Jonsson, 2012). In an advocacy context in the U.K., the Rural Creative Strategy - Independent Study Report (Bianchini et al., 2012, for the Rural Cultural Forum) commented on whether there might be an urban bias operating within strategic national arts and cultural funding policy and examined the needs of rural communities and artists, why a national rural cultural strategy may be necessary, and how such a strategy might align with other relevant government and stakeholder policy agendas in that country.

A strand of this research on rural creative economies focuses on the presence and fostering of creative industry clusters, that is, aggregates of firms. For example, some research has examined the tendency of certain types of creative industries to locate in rural and non-metropolitan areas, for example, the craft industry in Italy (Bertacchini and Borrione, 2013), and traditional creative and cultural activities (visual and performing arts, printing, libraries) in Victoria, Australia (Rural Councils Victoria, 2013). Within this literature, one also finds research on festivals and special events as attractors for visitors to rural and remote areas (e.g., Gibson and Stewart, 2009). From a policy-advocacy perspective, the work of the Rural Cultural Forum (mentioned above, derived from the Littoral Arts Trust), and the (more recently named) Creative Rural Industries Consortium has continued to advocate for support for "the new creative rural 
economies" in the United Kingdom, with an expanded scope beyond culture-based enterprises to incorporate "creative rural-based entrepreneurs" more widely (see, e.g., Creative Rural Industries Consortium, 2017a, 2017b, 2019).

As can be expected, critical voices quickly followed, highlighting context and local realities; for example, "Is culture-led redevelopment relevant for rural planners? The risk of adopting urban theories in rural settings" (Cruickshank, 2016, Norway). However, the trajectory continued to build steam. In Europe, Creative Industries in Peripheral Areas is published (Collins and Cunningham, 2017), asking: What are the operational challenges, and how can they be addressed? In the United States, the National Endowment for the Arts releases Rural Arts, Design, and Innovation in America: Research Findings from the Rural Establishment Innovation Survey (NEA, 2017). The latter is accompanied by the Wojan and Nichols (2018) article, "Design, innovation, and rural creative places: Are the arts the cherry on top, or the secret sauce?", promoted by Richard Florida (mentioned in the previous section). With this, lines of discourse on the rural creative class, the rural creative economy, and innovation begin to dovetail.

\section{Creative entrepreneurship in rural and remote areas}

This second stream focuses on the working realities of individual creators and culturebased/creative entrepreneurs located in rural areas. This small but growing literature examines the vitality and challenges of artistic/creative work and creative businesses in rural and peripheral settings, bursting onto the scene in 2011-2012 with three works: Marie-Anne Lenain's doctoral thesis on the dynamics of creative SMEs in three remote rural areas in France, and their situatedness between networks and territories (Lenain, 2011); Susan Luckman's book Locating Cultural Work: The Politics and Poetics of Rural, Regional and Remote Creativity, largely based on interviews with rural creators in Australia and the U.K. (Luckman, 2012); and Evangelia Petridou and Dimitri Ioannides's article on creative work ("conducting creativity") in the Jämtland region of Sweden, situating this work within a framework of territorial cohesion and spatial justice (Petridou and Ioannides, 2012).

Susan Luckman (2012) observes that the "rural creative economy" in England and Australia is composed of small companies that are driven by individual "creative" entrepreneurs. As with many creative and cultural entrepreneurs (HKU, 2010), these individuals are more likely to be focused on providing a livelihood for themselves than on business growth (Bell and Jayne, 2010; Herslund, 2012). They also tend to be more "socially embedded" than creative workers in an urban creative sector (Gibson et al., 2010; Bertacchini and Borione, 2013; Bennett et al., 2015), and motivated by non-economic reasons with value placed also on social returns such as enhancing local cultural life, facilitating social cohesion, and fortifying community spirit. Beyond economic returns, "other advantages" and contributions of the rural creative worker/practitioner include the provision of "organisational energy" and using their skills "for the betterment of the area" (Herslund, 2012, 253, 251). A danger of "individualizing" and "romanticizing" working practices in creative/cultural fields shadows this work, particularly in non-urban areas. As Collins and Cunningham (2017, 48) observe, "[t]he perception of individuals 'tuning out from the rate race' in pursuit of a more fulfilling career in creativity dominates not just the rhetoric, but policy to support the development of the creative economy in rural areas."

By 2015, research literature increasingly addresses the real nature of rural creative businesses and the expectations that have been projected onto them. For example, "Great expectations or small country living?," regarding the enabling of small rural creative businesses with ICT 
(Anderson et al., 2015), and "Living hand to mouth: Why the bohemian lifestyle does not lead to wealth creation in peripheral regions" (Bennett et al., 2015). This is closely accompanied by examinations of the practices that enable these businesses; for example, Munro's (2016) exploration of practices of market-building amongst creative entrepreneurs in rural and remote Scotland in "Developing the rural creative economy 'from below'."

In addition, a recent shift from creative to cultural entrepreneurship can be perceived in the research literature, reflecting the revival of craft production, which is increasingly enabled and sought after by rural, regional, and remote cultural workers/practitioners (Luckman, 2012; Collins and Cunningham, 2017). In 2017, the International Journal of Entrepreneurship and Innovation Management published a special issue on "Cultural Entrepreneurship and Regional Innovation" (Ratten and Ferreira, 2017). Greater attention to craft-art and artisan work is also evident in literature from Denmark (Prince, 2017), Portugal (Bakas et al., 2018), the Northern Isles of Scotland (McHattie et al., 2019), among other regions, often interwoven with rural tourism contexts and concerns.

\section{Towards mixed approaches and strategies}

The three storylines - cultural vitality, culture as resource for community development; the "rural creative class"; and rural creative economies and creative entrepreneurship - are still active, and a "weaving together" of these arguments and strategies into more consolidated platforms is needed to advance policy to foster and support cultural and creative work in rural areas. Academic efforts to develop consolidated approaches appeared around 2016-17, with a growing emphasis on strategy and policy. Notable in this output are, from Australia, Skippington's (2016) Harnessing the Bohemian: Artists as Innovation Partners in Rural and Remote Communities; from the United States, Balfour et al.'s (2018) article "The creative fire: An international framework for rural arts-based development"; and, from Norway, Lygard's (2016) article, "The 'actually existing' cultural policy and culture-led strategies of rural places and small towns." Jude Ortiz's (2017) doctoral dissertation, Culture, Creativity and the Arts: Building Resilience in Northern Ontario, mentioned earlier, can also be placed in this group.

In the policy and advocacy realm, as mentioned in the opening of this article, a recent wave of initiatives is also appearing, providing different platforms to inform the next wave of policy for cultural development in rural areas. While reminiscent of the 2005 studies in Michigan to identify support factors in small towns that can foster thriving arts communities, this is a much larger investigation. The pendulum, having swung into a period of parallel research trajectories, is once again swinging back to more holistic blended approaches to understanding systems and contexts.

\section{Informing policy / Extracting policy recommendations}

Within the diverse literature that has been produced internationally, researchers are calling for policy approaches and support for peripherally based creative and cultural entrepreneurs that are tailored to the unique features of their situations (e.g., Bell and Jayne, 2012; Luckman, 2012; Bennett et al., 2015). In general, the policy recommendations being put forward in research literature provide macro recommendations, noting the need to acknowledge differences among rural locations and circumstances, to enhance distinctiveness, and identify local cultural resources, both tangible and intangible. They acknowledge the multiple challenges to address - of distance/access, of critical mass, of soft infrastructure, of underdeveloped programmes and funding support - and the need for better knowledge. There is a general plea for place-specificity, to "listen to locals," and an emphasis on collaborative governance and policy-making processes. 
More specifically, regarding arts-based economic development on the scale of small communities, the policy recommendations being put forward in research literature tend to place an emphasis on four dimensions. First, there is an emphasis on individual artists by, for example, concentrating on the needs and characteristics of artists, emphasizing policy that supports artists through affordable live-work spaces, arts centers, and incubators that help artists network and become more skilled at running their businesses, and distribution of financial support to smaller arts organizations. Second, there is an emphasis on permanent arts facilities such as arts centers and incubators, viewing cultural assets as networks of resources and arts organizations to address neighbourhood-level problems and build community capacity (e.g., Balfour et al., 2018). Third, there is a wide-spread continued interest in urban-rural linkages and the broader networks in which rural producers operate (see, e.g., Cotte, 2019; Murphy and Cameron, 2020). Fourth, there is also a realization of the importance of networking within and across rural/remote territories (e.g., Ortiz, 2017; Gonçalves et al., 2020).

In terms of recommendations directed more to creative economy development in periphery regions, The Creative Edge Policy Toolkit (Collins et al., 2013) presents a comprehensive array of recommendations to foster creative entrepreneurship. The report highlights catalysts such as business hubs and low-cost work spaces to support emerging creative industries, fostering international cooperation between peripheral regions, enhancing virtual networking and connections among entrepreneurs, facilitating improved market access, and policy initiatives that are evidence-based and tailored to specific locales, needs, and market dynamics. The report also highlights the strategic potential of spill-over effects with other sectors of periphery economies.

Overall, attention to strategies of endogenous development and building capacity locally must balance efforts to attract creative entrepreneurs into a region. This is often missing from the literature on rural and remote cultural work, which tends to focus on attracting and retaining creative entrepreneurs from outside. Furthermore, it is not enough to attract creative talent to a rural or remote region, "it is even more important to retain such individuals as they are imperative to the development of these places" (Collins and Cunningham, 2017, 125). Studies on the retention of creative entrepreneurs in rural and remote areas have been rare. Cruz (2016) found the natural amenities that attract visitors and "creative class" residents to the Algarve region of Portugal are not sufficient to retain these creative residents if economic and entrepreneurship opportunities are not available. Bakas et al. (2018) investigated the artisan entrepreneur-mediators who link artisans to creative tourism in rural areas and small cities in Portugal, suggesting that the situations faced by the entrepreneur-mediators interviewed in the study point to the need to create policies with sufficient scope to ease the entry of non-local entrepreneurs, with low levels of social embeddedness, into rural communities.

Potential interfaces and interlinkages between cultural/creative initiatives and other social and economic sectors of small, rural, and/or remote communities are important cross-cutting considerations for policy-development, especially in smaller places with limited human and other resources. Bottom-up, community-engaged cultural and creative tourism, for example, provides a flexible and transversal platform for linking cultural, tourism, gastronomy, social innovation, and local development interests (see, e.g., Duxbury et al., 2019; Gonçalves et al., 2020). The growing prevalence of "place-making" as a collaborative platform for creative local development initiatives also requires more attention in the context of fostering cultural and creative initiatives in smaller places (e.g., Richards and Duif, 2018). In these initiatives, care must be taken not to look only at the contributions that cultural work might make to other policy 
agendas, but also "to recognize the inherent value and importance of culture per se" (O'Connell, 2020, 8).

Moving forward, it appears to be a time for stock-taking and projection, with further research needed to conduct a close theoretical tracing of the research literature and a close comparison and analysis of the emerging "mixed" frameworks. This must be complemented by detailed analysis of the policy recommendations embedded in the policy-related grey literature and inpractice policy frameworks of cultural agencies (and other bodies) internationally for cultural development and creative enterprises/entrepreneurship in rural and remote areas. The latter could potentially be launched through a "repeat" of IFACCA's 2006 international D' Art survey of arts councils and cultural agencies about cultural development in rural areas, expanding to incorporate "culture-based development" more generally. This work should be supported through ongoing networking and enhanced knowledge sharing between researchers and practitioners to build up a grounded knowledge of challenges, opportunities, and possible trajectories that can proactively, intelligently, and flexibly guide and foster cultural development and creative work in rural areas for the greater sustainability of the communities and territories in which they are situated.

\section{Acknowledgements}

This work was developed within the CREATOUR project, "Creative Tourism Destination Development in Small Cities and Rural Areas" (no. 16437), which is funded by the Portuguese Foundation for Science and Technology (FCT/MEC) through national funds and cofunded by FEDER through the Joint Activities Programme of COMPETE 2020 and the Regional Operational Programmes of Lisbon and Algarve. An earlier version of this article was a keynote presentation at the Nordic Conference on Cultural Policy Research, held at Bifröst University, Iceland, in 2019.

\section{References}

Andersen, L. 2010. Magic light, silver city: The business of culture in Broken Hill. Australian Geographer, 41(1), 71-85.

Anderson, A. R., C. Wallace and L. Townsend. 2015. Great expectations or small country living? Enabling small rural creative businesses with ICT. Sociologia Ruralis, 36(3), 450-468.

Anwar, J. 2005. An exploratory study of arts participation and wellbeing in regional Western Australia: A quantitative study of Denmark in the Great Southern Region. Unpublished thesis, Edith Cowan University, WA.

Anwar McHenry, J. 2011. Rural empowerment through the arts: The role of the arts in civic and social participation in the Mid West region of Western Australia. Journal of Rural Studies, 27(3), 245-253.

Argent, N., M. Tonts, R. Jones and J. Holmes. 2013. A creativity-led rural renaissance? Amenity-led migration, the creative turn and the uneven development of rural Australia. Applied Geography, 44, 88-98.

Bakas, F. E., N. Duxbury and T. V. de Castro. 2018. Creative tourism: Catalysing artisan entrepreneur networks in rural Portugal. International Journal of Entrepreneurial Behaviour and Research, 24. Special Issue on Artisan, Cultural and Tourism Entrepreneurship. Earlycite: doi:10.1108/ijebr-03-2018-0177. 
Balfour, B., M. W.-P. Fortunato and T. R. Alter. 2018. The creative fire: An interactional framework for rural arts-based development. Journal of Rural Studies, 63, 229-239. (online publication in 2016)

Bell, D. and M. Jayne. 2010. The creative countryside? Policy and practice in the UK rural cultural economy. Journal of Rural Studies, 26(3), 209-218. doi:10.1016/j.jrurstud.2010.01.001.

Bennett, D. 2010. Creative migration: A Western Australia case study of creative artists. Australian Geographer, 41(1), 117-128.

Bennett, S., S. McGuire, and R. Rahman. 2015. Living hand to mouth: Why the bohemian lifestyle does not lead to wealth creation in peripheral regions? European Planning Studies, 23(12), 2390-2403.

Bertacchini, E. and P. Borione. 2013. The geography of the Italian creative economy: The special role of the design and craft based industries. Regional Studies, 47(2), 135-147.

Bianchini, F., C. Bailey and S. Medlyn. 2012. Rural Cultural Strategy - Independent Study Report. Rural Cultural Forum, UK.

Bowles, K. 2008. Rural cultural research: Notes from a small country town. Australian Humanities Review, no. 45.

Burns, J. and C. Kirkpatrick. 2008. Creative Industries in the Rural East Midlands-Regional Study Report. Culture East Midlands.

Campbell, H. and F. Maclaren. Forthcoming. Small growth: Cultural heritage and coplacemaking in Canada's post-resource communities. In N. Duxbury (ed.), Cultural Sustainability, Tourism and Development: (Re)articulations and Dynamics. London: Routledge.

Collins, P. and J. A. Cunningham. 2017. Creative Economies in Peripheral Regions. Palgrave Macmillan.

Collins, P., J. Cunningham, A. Murtagh and J. Dagg. 2013. The Creative Edge Policy Toolkit. Galway: The Whitaker Institute, National University of Ireland.

Collis, C., S. Freebody and T. Flew. 2013. Seeing the outer suburbs: Addressing the urban bias in creative place thinking. Regional Studies, 47(2), 148-160.

Cotte, A. (Ed.). 2019. Culture Crops: Cultural Practices in Non-urban Territories Conference Report. Brussels: Culture Action Europe.

Creative Rural Industries Consortium. (2017a, revised 2019). The Future is Rural: The New Creative Rural Economies - A Creative Rural Industries sector manual and information resource. Compiled by Ian Hunter, Littoral Arts Trust.

Creative Rural Industries Consortium. (2017b, revised 2019). The New Creative Rural Economies - Appendices. Compiled by Ian Hunter, Littoral Arts Trust.

Creative Rural Industries Consortium. (2019, March). The New Creative Rural Economies. fl4 billion p.a. to the creative economy by 202S'? The creative rural sector responds to the Government's Industrial Strategy, Creative Industries Sector settlement. (Tate Britain Conference report). Compiled by Ian Hunter, Littoral Arts Trust.

Cruickshank, J. 2016. Is culture-led redevelopment relevant for rural planners? The risk of adopting urban theories in rural settings. International Journal of Cultural Policy, 24(3), 331-349. doi:10.1080/10286632.2016.1178732.

Cruz, A. R. 2016. 'A place in the sun: Tourism's contribution to the creative dynamics and the attraction of the creative class in the Algarve'. PhD thesis, University of the Algarve, Portugal.

Cuesta, C., D. M. Gillespie and P. Lillis. 2005. Bright Stars: Charting the Impact of the Arts in Rural Minnesota. Minneapolis: The McKnight Foundation.

Daniel, R. 2014. Building the northern Australia vision through creative industries: The case of Cairns in far north Queensland. Creative Industries Journal, 7(2), 134-147. 
Denis-Jacob, J. 2012. Cultural industries in small-sized Canadian cities: Dream or reality? Urban Studies, 1-18. doi:10.1177/0042098011402235.

Donald, B. (Ed.) 2008. Growing the Creative Rural Economy in Prince Edward County: Strategies for Innovative, Creative and Sustainable Development. Kingston, ON: Queen's University.

Donald, B. and H. Hall. 2014. Artful Places: Cultivating Arts, Culture and Nature in Rural Development. Kingston, ON: The Monieson Centre at Queen's School of Business.

Drake, G. 2003. 'This place gives me space': Place and creativity in the creative industries. Geoforum, 34, 511-524.

Duxbury, N. 2010. "Revitalizing Rural Communities through Arts and Culture: International Trends and Insights." In Proceedings of 'Mundos Rurais em Portugal: Múltiplos Olhares, Múltiplos Futuros, ' IV Congresso de Estudo Rurais, Aveiro, February 4-6, 2010. Lisboa: Sociedade Portuguesa de Estudos Rurais.

Duxbury, N. and Campbell, H., 2009. Developing and Revitalizing Rural Communities through Arts and Creativity: A Literature Review. Vancouver: Creative City Network of Canada.

Duxbury, N., S. Silva and T. V. de Castro. (2019). Creative tourism development in small cities and rural areas in Portugal: Insights from start-up activities. In D. A. Jelinčić and Y. Mansfeld (Eds.), Creating and Managing Experiences in Cultural Tourism (pp. 291304). Singapore: World Scientific Publishing.

Felton, E. and C. Collis. 2012. Creativity and the Australian suburbs: The appeal of suburban localities for the creative industries workforce. Journal of Australian Studies, 36(2), $177-190$.

Florida, R. 2002. The Rise of the Creative Class: And How It's Transforming Work, Leisure, Community, and Everyday Life. New York: Basic Books.

Florida, R. 2018. The rise of the rural creative class. CityLab, May 1.

Future Tense. 2018. What makes a creative community? What does it need to thrive? Creative Ecologies: An investigation. Creative Ecologies initiative, undertaken in partnership with Artlands Victoria, RMIT University, Ludowyk Evaluation and Clear. https://creativeecologies.net/uploads/Creative-Ecologies Findings-Report.pdf

Gibson, C. (Ed.) 2010. Special issue: "Creativity in 'Peripheral' Areas: Redefining the Creative Industries. Australian Geographer, 41(1).

Gibson, C. (Ed.) 2014. Creativity in Peripheral Places: Redefining the Creative Industries. Routledge.

Gibson, C. and N. Klocker. 2005. The 'cultural turn' in Australian regional economic development discourse: Neoliberalising creativity? Geographical Research, 43(1), 93102.

Gibson, C., S. Luckman and J. Willoughby-Smith. 2010. Creativity without borders? Rethinking remoteness and proximity. Australian Geographer, 41(1), 25-38

Gibson, C. and A. Stewart. 2009. Reinventing rural places: The extent and impact of festivals in rural and regional Australia. Wollongong, Australia: University of Wollongong.

Gonçalves, A. R., R. Borges, N. Duxbury, C. Pato Carvalho and P. Costa. 2020. Policy Recommendations on Creative Tourism Development in Small Cities and Rural Areas. Coimbra: CREATOUR project, Centre for Social Studies, University of Coimbra.

Grodach, C. and A. Loukaitou-Sideris. 2007. Cultural development strategies and urban revitalization. International Journal of Cultural Policy, 13(4), 349-370.

Haisch, T., F. H. J. M. Coenen, and J. D. S. Knall. 2017. Why do entrepreneurial individuals locate in non-metropolitan regions? International Journal of Entrepreneurship and Innovation Management, 21(3), 212-233. 
Hart, K. 2020. Coronavirus may prompt migration out of American cities. The Harris Poll, April 30. https://theharrispoll.com/coronavirus-may-prompt-migration-out-ofamerican-cities/

Herslund, L. 2012. The rural creative class: Counterurbanisation and entrepreneurship in the Danish countryside. Sociologia Ruralis, 52(2), 235-255.

HKU. 2010. The Entrepreneurial Dimension of the Cultural and Creative Industries. Utrecht: Hogeschool vor de Kunsten Utrecht.

Hracs, B. 2005. Culture in the Countryside: A Study of Economic Development and Social Change in Prince Edward County, Ontario. Toronto: York University, Master's thesis.

Lenain, M.-A. F. (2011, December 16). Dynamiques et accompagnement des TPE inventives en espace rural isolé : entre territoires et réseaux : l'exemple en Cézallier, Combrailles et Millevaches. PhD thesis, Géographie. Université Blaise Pascal - Clermont-Ferrand II, France.

Lewis, N. M. and B. Donald. 2010. A new rubric for 'creative city' potential in Canada's smaller cities. Urban Studies, 47(1), 29-54.

Long, P. and N. D. Morpeth (Eds.) 2016. Tourism and the Creative Industries: Theories, Policies and Practices. Routledge.

Luckman, S. 2012. Locating Cultural Work: The Politics and Poetics of Rural, Regional and Remote Creativity. Palgrave Macmillan.

Lygard, H. K. 2016. The 'actually existing' cultural policy and culture-led strategies of rural places and small towns. Journal of Rural Studies, 44, 1-11.

MacDonald, S. 2011. Joined Up Creativity: Creative Industries and Scotland's Urban and Rural Creative Economy. Keynote address at Creative Rural Economy: From Theory to Practice Conference, Kingston, Ontario, Canada, June 14, 2011.

Markusen, A. 2007. An arts-based state rural development policy. Journal of Regional Analysis \& Policy, 37(1): 7-9.

Markusen, A. and G. Schrock. 2006. The artistic dividend: Urban artistic specialisation and economic development implications. Urban Studies, 43(10), 1661-1686.

Martin Prosperity Institute. (2011). Final Report - Eastern Ontario: Canada's Creative Corridor. Creative Rural Economy Initiative. Toronto: Martin Prosperity Institute, University of Toronto.

Mass Culture/Mobilisation Culturelle. 2019. Digital Gathering II: Cultural Development in Rural and Remote Areas [webinar], March 1. Recording available: https://massculture.ca/gatherings/digital-gatherings/digital-gathering-2/

McCool, S. F. and R. N. Moisey (Eds.) 2001. Tourism, Recreation and Sustainability: Linking Culture and the Environment. New York: CABI Publishing.

McGranahan, D. A. and T. R. Wojan. 2007a. Recasting the creative class to examine growth processes in rural and urban counties. Regional Studies, 41(22), 197-216.

McGranahan, D. A. and T. R. Wojan, 2007b. The creative class: A key to rural growth. Amber Waves, 5(2): 16-21.

McHattie, L.-S., K. Champion and M. Johnson. 2019. Crafting the local: The lived experience of craft production in the Northern Isles of Scotland. Cultural Trends, 28(4), 305-316.

McManus, P. and J. Connell. 2008. Country week: Bringing the city to the country? Australian Humanities Review, No. 45.

Munro, E. (2016) Developing the rural creative economy 'from below': exploring practices of market-building amongst creative entrepreneurs in rural and remote Scotland. $M / C$ Journal, 19(3). http://journal.mediaculture.org.au/index.php/mcjournal/article/view/1071

Murphy, A. and G. Cameron (Eds.). 2020. Voices of Culture: The Role of Culture in Non-urban Areas of the European Union. Brussels: Goethe Institut. 
National Endowment for the Arts (NEA). 2017. Rural Arts, Design, and Innovation in America: Research Findings from the Rural Establishment Innovation Survey. Washington, DC: NEA.

Nelson, R., N. Duxbury and C. Murray. 2012. Cultural and creative economy strategies for community transformation: Four approaches. In J. Parkins and M. Reed (Eds.), The Social Transformation of Rural Canada: New Insights into Community, Culture and Citizenship (pp. 368-386). Vancouver: University of British Columbia Press.

Noda, K. 2018. The agglomeration of creative people and regional revitalization in a small town: A focus on Fujino, Japan. Presentation at $10^{\text {th }}$ International Conference on Cultural Policy Research, Tallinn, Estonia, August 23, 2018.

O'Connell, V. 2020. The role of culture in rural, peri-urban, in-between and/or un(der)used non-urban areas. In A. Murphy and G. Cameron (Eds.), Voices of Culture: The Role of Culture in Non-urban Areas of the European Union (pp.6-26). Brussels: Goethe Institut.

Ortiz, J. 2017. 'Culture, Creativity and the Arts: Building Resilience in Northern Ontario'. PhD dissertation, University of the West of England, Bristol, UK.

Overton, P. 2009. Developing and Revitalizing Rural Communities through Arts and Creativity: United States of America. Vancouver: Creative City Network of Canada.

Petridou, E., and D. Ioannides. 2012. Conducting creativity in the periphery of Sweden: A bottom-up path towards territorial cohesion. Creative Industries Journal, 5 (1-2), 119 137.

Prince, S. 2017. Craft-art in the Danish countryside: Reconciling a lifestyle, livelihood and artistic career through rural tourism. Journal of Tourism and Cultural Change, 15(4), 339-358.

Ratten, V. and J. J. Ferreira. 2017. Future research directions for cultural entrepreneurship and regional development. International Journal of Entrepreneurship and Innovation Management, 21(3), 163-169. Special issue: Cultural Entrepreneurship and Regional Innovation.

Richards, G. and L. Duif. 2018. Small Cities with Big Dreams: Creative Placemaking and Branding Strategies. London: Routledge.

Rightmove. 2020. Buyers look out-of-city and home-movers determined to move post lockdown. https://www.rightmove.co.uk/press-centre/buyers-look-out-of-city-andhome-movers-determined-to-move-post-lockdown/

Roberts, E. and Townsend, L. 2016. The contribution of the creative economy to the resilience of rural communities: Exploring cultural and digital capital. Sociologia Ruralis, 56(2), 197-219.

Rodning Bash, S. 2006. Thriving Arts: Thriving Small Communities. St. Paul: MN: Metropolitan Regional Arts Council.

Rood, S. (NGA Center for Best Practices). 2019. Rural Prosperity through the Arts \& Creative Sector: A Rural Action Guide for Governors and States. Washington, DC: National Governors Association (NGA) and National Endowment for the Arts.

Rooney, M. and R. Smith (Eds.). 2008. Special issue: Rural cultural studies. Australian Humanities Review, no. 45.

Rural Councils Victoria. 2013. Creative Industry in Rural Victoria. Melbourne: Rural Councils Victoria.

Selfa, T., Iaroi, A., and Burnham, M. 2015. Promoting ethanol in rural Kansas: Local framings and cultural politics. Journal of Rural Studies, 39, 63-73.

Shifferd, P. A. 2005. The Arts in Small Communities: Report of a Study of Ten Minnesota Towns. St. Paul: MN: Metropolitan Regional Arts Council.

Skippington, P. 2016. Harnessing the Bohemian: Artists as innovation partners in rural and remote communities. Acton: ANU Press. https://www.jstor.org/stable/j.ctt1q1crpj.1 
Skippington, P. A. and D. F. Davis. 2016. Arts-based community development: Rural remote realities and challenges, Rural Society, 25(3), 222-239. doi:10.1080/10371656.2016.1255477.

Skoglund, W. and G. Jonsson. (2012). The potential of cultural and creative industries in remote areas. Nordisk kulturpolitisk tidsskrift, 15(2), 181-191.

Smiles, R. 2006. Cultural Development in Rural and Remote Areas. D’Art no. 23. Sydney: International Federation of Arts Councils and Culture Agencies.

van Heur, Bas. 2010. Small cities and the geographical bias of creative industries research and policy. Journal of Policy Research in Tourism, Leisure and Events, 2(2), 189-192.

Verdich, M. 2010. Creative migration? The attraction and retention of the creative class in Launceston, Tasmania. Australian Geographer, 41(1), 129-140.

Verdini, G. and P. Ceccarelli. 2017. Creative small settlements: Culture-based solutions for local sustainable development. Research report for UNESCO. London: University of Westminster.

Vodden, K., R. Gibson and G. Baldacchino. (Eds.) 2015. Place Peripheral: Place-Based Development in Rural, Island and Remote Regions. St. John's: ISERBooks.

Wojan, T. R., D. M. Lambert and D. A. McGranahan. 2007. Emoting with their feet: Bohemian attraction to creative milieu. Journal of Economic Geography, 7(6), 711-736.

Wojan, T. R. and B. Nichols. 2018. Design, innovation, and rural creative places: Are the arts the cherry on top, or the secret sauce? PLoS ONE, 13(2), e0192962. doi:10.1371/journal.pone.0192962.

Woods, M. 2012. Creative Ruralities. Paper presented to the 'Creativity on the Edge' Symposium, Moore Institute, National University of Ireland Galway, June 2012.

Yuzwa, J. 2017. 'Beyond the Metro: Culture-Led, Creative Industry Initiatives and Rural cultural Sustainability on Gabriola Island, B.C. Doctoral research in progress'. Presentation at the B.C. Studies Conference, Vancouver Island University, Nanaimo, British Columbia, Canada, May 2017. 